\title{
Growth and ectomycorrhization of banj oak plants co-inoculated with Scleroderma bovista and mycorrhizosphere bacteria
}

\author{
Anurag Yadav ${ }^{*}$, R.C. Dubey ${ }^{2}$ and Kusum Yadav \\ ${ }^{1}$ Department of Microbiology, College of Basic Science and Humanities, S.D. Agricultural University, S.K. Nagar \\ (Gujarat), INDIA \\ ${ }^{2}$ Department of Botany and Microbiology, Gurukula Kangri Vishwavidyalaya, Haridwar-249404 (Uttarakhand), \\ INDIA \\ ${ }^{3}$ Department of Biochemistry, University of Lucknow, Lucknow (Uttar Pradesh), INDIA \\ *Corresponding author. E-mail: anuragyadav123@gmail.com \\ Received: August 21, 2014; Revised received: November 30, 2014; Accepted: April 15, 2015
}

\begin{abstract}
Effect of composite treatment of ectomycorrhizal fungus (EMF), Scleroderma bovista, along with mycorrhizosphere bacterial inoculants was studied for nine months on Quercus leucotrichophora plants grown in nursery glasshouse. Seven treatments comprising of one uninoculated control; two bacterial controls, Bacillus subtilis MB14 and Pseudomonas fluorescens MB 9, respectively; EMF control, S. bovista; two combinations of two bacterial treatments with EMF and one triple treatment of two bacteria with EMF, were used in the study. The ninth month of sampling showed that triple treatment of two strains of bacteria with EMF maximally enhanced root length $(38.86 \mathrm{~cm})$, dry weight $(6.746 \mathrm{~g})$, short roots (351.6), lateral roots (24.8) and EMF colonization (34.8\%) of banj oak plant, which was fairly higher than uninoculated and bacterial controls. Bacteria treated plants showed no plant growth enhancement, whereas EMF treatment fairly enhanced plant growth. The co-inoculation practice can help oak plant in achieving the mycorrhization rate even with lower EMF doses. These findings will be beneficial for achieving the effective banj oak replantation in the Himalayan region.
\end{abstract}

Keywords: Ectomycorrhiza, Growth enhancement, Mycorrhiza helper bacteria, Scleroderma bovista

\section{INTRODUCTION}

Quercus leucotrichophora (ban oak or banj oak) is a moderate-sized large evergreen tree with massive gnarled branches and rounded crowns. It is the chief oak species of Western Himalayan mountains and constitute dense forest patches in the region (Singh and Rawat, 2012). The oak (Quercus spp.) forests of Western Himalayan Mountains are known for their ecologically protective and productive nature. From past few decades the ecology of these forests has become severely disturbed. The forest covers have undergone significant compositional changes due to forest clearing, fire, illegal cutting for firewood (Kumar and Ram, 2005; Kumar and Sharma, 2009; Singh and Rawat, 2012). One of the most critical issues related to deforestation is the risk of erosion and landslides, which reduce soil fertility and water catchments quality.

There is an urgent need for sustaining the rich biodiversity of Western Himalayan region. Although forest plantation with several species of Quercus are under process at few places in the Western Himalayan mountain range but often the plants die in forests. The successful plantation requires implementation of effective reforestation program, which could be achieved by transplanting nursery grown plants in the forest. The effectiveness of reforestation program can fairly be enhanced by transplanting nursery plants compositely treated with appropriate ectomycorrhizal fungal and bacterial inoculants (Kropp and Langlois, 1990).

Ectomycorrhizal fungi along with other beneficial soil organisms interact to produce a variety of favorable effects on plants, which are not possible with chemical fertilizers. Co-inoculation practices increase the plant biomass without affecting its root-shoot ratio. The stimulatory bacterial isolates of mycorrhizosphere could be of special interest in improving mycorrhizal inoculation techniques in forest nurseries. Moreover, by employing composite treatment of mycorrhizosphere bacteria the same mycorrhizal rate can be obtained with lower doses of EMF inoculum (Aspray et al., 2006). In reforestation programs such interactions are considered beneficial for plant survival. In light of the above facts, the study was designed to evaluate the effect of EMF along with some mycorrhizosphere bacteria on the growth of banj oak plants.

\section{MATERIALS AND METHODS}

The study was conducted in the glasshouse of Sleepy Hollow Nursery, Kumaun University, Nainital. Monsoon pattern of rainfall influences the climate of Nainital. The annual rainfall of this region varies from $2600 \mathrm{~mm}$ 
to $2900 \mathrm{~mm}$. The soil mixture used in the experiment was sandy silt with $6.2 \%$ clay content (Table 1 ).

Collection of seeds: The fallen healthy acorns of banj oak were collected from oak tree in early March. Seeds were collected from the same tree to overcome genetic variations. Seeds were washed with plenty of tap water, soaked in mild detergent and re-washed three or four times. Seeds were surface sterilized by soaking in 30\% $\mathrm{H}_{2} \mathrm{O}_{2}$ for 15 minutes (Hauer and Dawson, 1996). After sterilization the seeds were immediately washed with 2 $\mathrm{L}$ sterilized with sterilized doubly distilled water $\left(\mathrm{ddH}_{2} \mathrm{O}\right)$ to remove $\mathrm{H}_{2} \mathrm{O}_{2}$ traces. The seeds were then placed in plates containing sterilized, acid-washed and neutralized sand in germination chambers for germination at $25^{\circ} \mathrm{C}$ for 25 days.

Fungal inoculum preparation: Mass inoculum of Scleroderma bovista was prepared by gently floating agar discs containing EMF inoculum on Modified Melin Norkrans (MMN) (Marx, 1970) broth in 1 L Erlenmeyer flasks, aseptically. These flasks were kept at $25^{\circ} \mathrm{C}$ for one month in a rotary shaker at $60 \mathrm{RPM}$. Fungal mycelia were separated from the medium by pouring the broth in a funnel contained in a flask with Whatman filter paper. The mycelia were mixed in an electric blender for breaking and thorough mixing of hyphae (Sim and Eom, 2006).

Bacterial inoculum preparation: Mycorrhizosphere bacteria screened from previous experiments (Yadav et al., 2001) and checked for in vitro helper effect (data not shown), were used. Mass bacterial culture was done in $1 \mathrm{~L}$ flasks containing nutrient broth medium. These flasks were incubated at $30^{\circ} \mathrm{C}$ for four days.

Potting mixture preparation: Potting mixture was prepared by mixing sand and soil in 3:1 ratio (Table 1). The mixture was autoclaved at $20 \mathrm{lbs} \mathrm{inch}^{-2}$ for 20 minutes for two subsequent days (Rizvi and Khan, 2009; Sim and Eom, 2006). After cooling the soil mixture to room temperature the helper bacteria contained in nutrient broth and EMF mycelium were sprayed on the soil mixture at the dose of $10^{8}$ bacteria/mycelia $\mathrm{g}^{-1}$ soil and mixed with hands. About $1.5 \mathrm{~kg}$ of soil mixture was used for filling polybags $(15 \times 23 \mathrm{~cm})$.

Nursery experiment: A mixture of soil and sand in polybags was inoculated with various combinations of bacterial suspension and S. bovista. Four controls used in the experiment were, i) the uninoculated control, ii) inoculated fungal control (EMF) and two bacterial controls, iii) B1 and iv) B2. The three inoculum treatment combinations used were $S$. bovista with $B$. subtilis (EMF+B1), S. bovista with P. fluorescens (EMF+B2) and $S$. bovista with $B$. subtilis and $P$. fluorescens $(\mathrm{EMF}+\mathrm{B} 1+\mathrm{B} 2)$. One month old $Q$. leucotrichophora plants were planted in polybags containing $1.5 \mathrm{~kg}$ sandy silt soil treated with desired inoculum. The plants were transported to the green house in sleepy hollow nursery at Kumaun University, Nainital. Watering of nursery plants was done after every 15 day interval

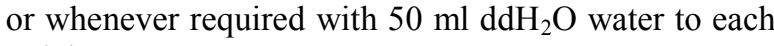
polybag.

Plant growth parameters were tri-monthly checked for nine months. Five replicates of plant from seven treatments were arranged in randomized block design. For sampling, plants were randomly selected, their polybags were removed and soil sticking to the roots was gently brushed off. Plant roots were gently washed in running tap water to remove adhering soil particles. The root system of plants was thoroughly washed with running tap water and blot dried. Plants were kept overnight in oven at $85^{\circ} \mathrm{C}$. Thereafter the plants were removed from oven and immediately weighed with electronic balance for dry weight estimation. Plant short roots and mycorrhizal tips were identified and counted with the help of a magnifying glass. Root tip was considered mycorrhizal when appeared white or cream colored and swollen. Ectomycorrhizal roots were microscopically examined by staining the T.S. of roots with cotton blue and lactophenol. The treatment effect on plant growth was analyzed by one way analysis of variance (ANOVA).

\section{RESULTS}

Plant root length, shoot length and collar diameter: There was a gradual temporal enhancement of root length, shoot length and collar diameter of $Q$. leucotrichophora in all treatments (Fig. 1). Composite plant inoculation treatments resulted in positive change of similar intensity on root length, shoot length and collar diameter, which was considerably higher than uninoculated and inoculated bacterial (B1 and B2) and fungal (EMF) controls. The ninth month of observation showed that triple inoculation (S. bovista with B. subtilis MB14 and $P$. fluorescens MB9) yielded maximum root length $(38.86 \mathrm{~cm})$, which was higher than uninoculated control and inoculated fungal and bacterial controls. Maximum shoot length $(15.26 \mathrm{~cm})$ and collar diameter $(0.320 \mathrm{~cm})$ was observed with dual treatment of plant with $S$. bovista and P. fluorescens MB9. No ectomycorrhizal was observed in uninoculated control and in bacterial treatment controls.

Plant dry weight: With the final observation of the ninth month, maximum plant dry weight was observed with triple treatment $(6.746 \mathrm{~g})$ followed by dual treatment of EMF with B. subtilis (Fig. 2). The root-shoot dry weight ratio decreased with each observation month for the same treatment. Lowest dry root-shoot ration was observed with EMF+ B2 (1.168) whereas the highest ratio was observed with uninoculated control (1.646). Overall dry root-shoot ratio of oak plants decreased with increase in inoculation treatment level in the order of uninoculated control $>S$. bovista with $B$. subtilis MB14> B. subtilis $\mathrm{MB} 14>P$. fluorescens MB9 $>S$. bovista with $B$. subtilis MB14 and $P$. fluorescens MB9 $>S$. bovista $>S$. bovista with $P$. fluorescens MB9.

Number of short roots, lateral roots and EMF colonization: There was a consistent temporal enhancement in the number of lateral and short roots within each treatment 
Table 1. Characteristics of soil mixture used in the experiment.

\begin{tabular}{ll}
\hline Parameter & Value \\
\hline Organic carbon & $2.70 \%$ \\
Total nitrogen & $0.26 \%$ \\
Available phosphorus & $0.0084 \%$ \\
Carbon/Nitrogen ratio (C:N) & 10.38 \\
Water holding capacity & $7.94 \%$ \\
Sand & $72.80 \%$ \\
Silt & $21.0 \%$ \\
Clay & $6.2 \%$ \\
pH & 6.42 \\
Moisture & $22.08 \%$ \\
\hline
\end{tabular}

(Fig. 3). In the final observation of ninth month, composite treatment of EMF with bacterial inoculants on oak plant enhanced the number of short roots, lateral roots and EMF colonization. No EMF colonization was observed in uninoculated control and two bacterial controls. Triple treatment maximally enhanced short roots (351.6), lateral roots (24.8) and EMF colonization (34.8\%) of $Q$. leucotrichophora.

Ordinate analysis shows that the observed values of EMF inoculated treatments were much different from non-treated once (Fig. 4). Also maximum EMF colonization, Hartig net thickness and fungal mantle thickness were observed with triple treatment. The significant positive regression $\left(\mathrm{R}^{2}=\right.$ 0.946) of EMF \% on fungal mantle length was observed (Fig. 5). The one way ANOVA showed significant $(\mathrm{p}<0.01)$ differences of treatment variation on all the tested plant growth parameters.

In vitro growth enhancement of Pisolithus tinctorius and Hebeloma crustuliniforme has been reported from Azospirillum brasilense and Bacillus polymyxa in liquid medium (Dahm et al., 1998). Likewise, in vivo helper effect has been reported on Laccaria laccata with B. amyloliquefaciens on Douglas fir with 60-80\% mycorrhization increase (Duponnois and Garbaye, 1991), L. laccata with Agrobactrium sp. on Pinus sylvestris (Leyval and Berthelin, 1991), L. laccata with B. subtilis, Bacillus sp., P. fluorescens and Pseudomonas sp. on Douglas fir (Duponnois and Garbaye, 1992), L. lacata with P. fluorescence on Q. robur with 30 to $53 \%$ mycorrhization increase (Garbaye et al., 1992), Laccaria bicolor with P. fluorescens BBc6 on Douglar fir with $70 \%$ mycorrhization increase (Frey-Klett et al., 1997), Amanita muscaria and Suillus bovinus with Streptomyces on Picea abies and Pinus sylvestris for $20 \%$ to $70 \%$ mycorrhizan increase (Schrey et al., 2005), Pisolithus alba with fluorescent pseudomonad strains HR13 and HR26 on Acacia hilosericea (Founoune et al., 2002a) and on Australian acacia species with Psedudomonas monteilii HR13 (Duponnois and Plenchette, 2003).

\section{DISCUSSION}

Mycorrhizosphere harbors vivid microbial community and is considered rich in plant health promoting rhizobacteria (Budi et al., 1999). These helper bacteria when co-inoculated with ectomycorrhizal fungi facilitates plant growth by inhibiting plant pathogens (Schelkle and Peterson, 1997), IAA production (Garbaye, 1994a), affecting the receptivity of root, secreting phenolic compounds, which increase the symbiotic efficacy of EMF (Garbaye, 1994b). Some of these bacteria behave as independent helpers by producing antifungal compounds, by antagonism through antibiosis and by cell wall breakdown with the help of cell-wall-degrading enzymes (Mahaffee and Kloepper, 1997).

By using plant helping bacteria the mycorrhizosphere can be tailored to obtain desirable plant growth and EMF development. EMF development in turn positively influences mycorrhizosphere bacterial community structure related to carbon source utilization (Heinonsalo et al., 2000) by creating a symbiotic environment which is beneficial for fungal and bacterial partners. Bacillus spp. and Pseudomonas spp. are potential candidates to be used in biofertilizer industry because they are dominant in rhizosphere and possess the ability to compete with pathogens to improve plant health. Bacillus sp. dominates in the rhizosphere as a result of its endospore forming property which helps this bacteria to tolerate heat, acidity and salinity (Mahaffee and Kloepper, 1997; Weller, 1988). A large number of $B$. subtilis strains have been reported to suppress the growth of several pathogenic fungi by producing antifungal substances such as iturin A, amicoumacin (Pinchuk et al., 2002), surfactin (Souto et al., 2004) and group of similar cyclic lipopeptides (Gong et al., 2006). P. fluorescens as a bionioculant was preferred in the study because it is known to produce pyrrolnitrin, antifungal compound (Ligon et al., 2000) and siderophores. Bacterial cells are able to sequester iron (III) from rhizosphere soil in the form of siderophores, thus the reducing iron availability to the pathogen (Yang and Crowley, 2000). Enhanced iron availability, in the form of siderophore, in mycorrhizosphere could also improve Fe absorption by EMF fungus. EMF fungus, S. bovista, was used as fungal counterpart of the biofertilizer for the reason that this fungus is well adapted to the Himalayan environment and predominantly distributed throughout the region (Aryal and Budathoki, 2013; Yadav and Yadav, 2012). Mushrooms of this fungus, being of puffball nature produce numerous enclosed spore-bearing structures (Sarwar et al., 2013).

The results show that the growth of $Q$. leucotrichophora was considerably enhanced when inoculated with $S$. bovista. The growth enhancement was more prominent when $S$. bovista was applied along with $B$. subtilis MB14 and P. fluorescens MB9. In a similar study considerable helper effect was noticed on the ectomycorrhiza formation from Laccaria fraterna on Eucalyptus diversicolor plants 

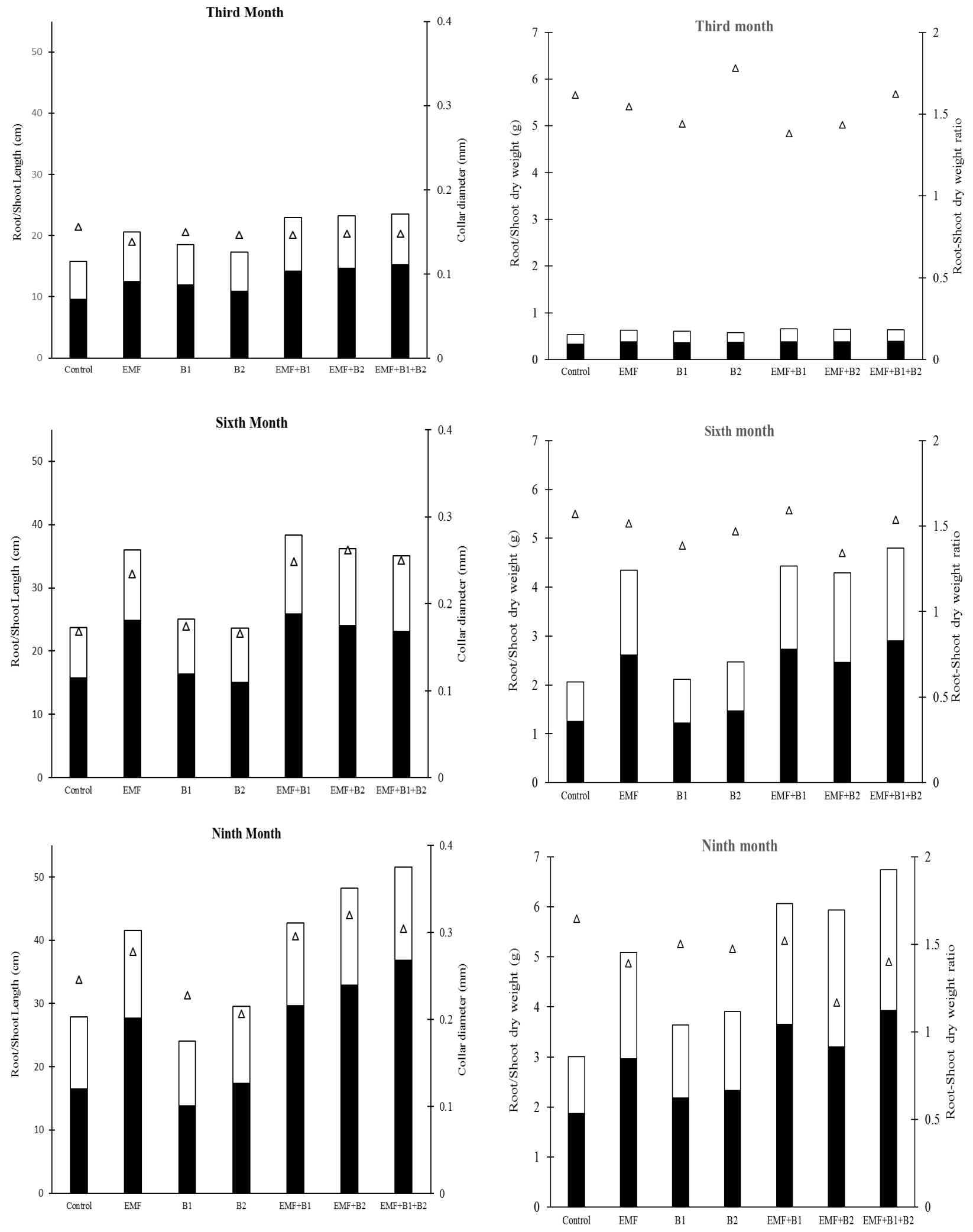

Fig. 1. Sampling months showing root length (filled bars), shoot length (hollow bars) and collar diameter (hollow triangles) of $Q$. leucotrichophora.

Fig. 2. Sampling months showing dry root weight (filled bars), dry shoot weight (hollow bars) and root-shoot ratio (hollow triangles) of $Q$. leucotrichophora. 

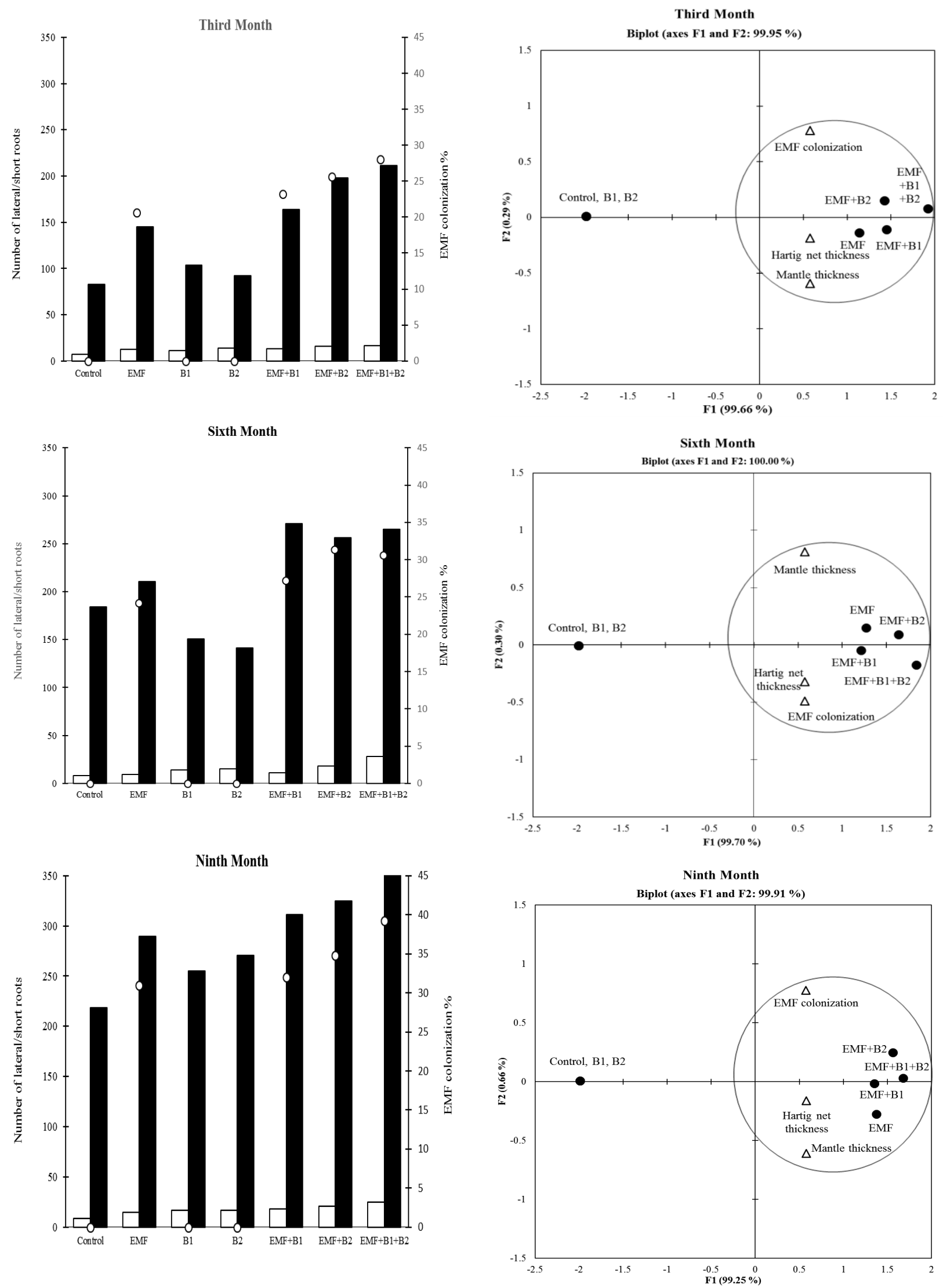

Fig. 3. Sampling months showing number of lateral roots (hollow bars), short roots (filled bars) and EMF colonization (hollow circles) of $Q$. leucotrichophora.

Fig. 4. Ordinates showing fungal mantle thickness, Hartig net thickness and EMF colonization of $Q$. leucotrichophora seedling treatments. 
when treated with P. fluorescens BBc6, B. subtilis MB3, Bacillus sp. Elf28 and pseudomonad Elf29, respectively (Dunstan et al., 1998). Their results show that the plants which were inoculated only with Bacillus sp. (Elf28) still had higher shoot dry weight than with untreated plants and the plants treated with L. bicolor (S238). The result of Dunstan et al. (1998) was contradictory to our results where the treatment with B. subtilis MB14 or P. fluorescens MB9 had no effect on plant growth. In our results, treatment of B. subtilis MB14 or $P$. fluorescens MB9 with $S$. bovista increased $Q$. leucotrichophora short roots very similarly as obtained by adding exogenous IAA. In a similar study, strains of P. fluorescens with Laccaria bicolor were reported to increase the number of short roots of Norway spruce (Picea abices) (Karabaghli et al., 1998). Composite treatment of EMF with B. subtilis MB14 or P. fluorescens MB9 enhanced root and shoot biomass of oak plant. In a similar study, infection of Pisolithus alba was reported to increase root and shoot biomass of Acacia hilosericea when co-inoculated with fluorescent pseudomonad strains (HR13 and HR26) (Founoune et al., 2002b).

Principal component analysis (PCA) from ninth month of sampling show that the treatment of S. bovista effectively enhanced plant root and shoot height and dry weight. The plant growth enhancement was further alleviated when $S$. bovista was used with B. subtilis MB14 or P. fluorescens MB9. Triple treatment of $S$. bovista with B. subtilis MB14 and P. fluorescens MB9 maximally enhanced fungal mantle thickness (44.26 $\mu \mathrm{m})$, Hartig net thickness $(35.66 \mu \mathrm{m})$ and EMF colonization (39.2\%), which was much higher than the uninoculated control (Fig. 4). This enhancement was probably due to greater allocation of metabolites arranged by $B$. subtilis MB14 and P. fluorescens MB9. Many helper bacteria have been reported to release iron from a mineral, biotite, in oak-S. citrinum ectomycorrhiza (Uroz et al., 2007). It is also hypothesized that dual or triple inoculation enhances the plant photosynthetic rate, which enhances the mobilization of soluble sugars to host roots, thus increasing fungal growth and activity in the roots (Amijee et al., 1989; Hetrick, 1989). The ability of helper bacteria to increase EMF colonization suggests a direct bacterial effect on the metabolic status of EMF fungi. These bacteria survive well in the trehalose rich environment of vegetative fungal hyphae (Danell et al., 1993).

In winter season EMF mantle and Hartig net thickness of all the treatments decreased during ninth month of observation probably due to the lower temperature effect of winter season. In uninoculated control and single treatments of B. subtilis MB14 and P. fluorescens MB14, no EMF colonization, mantle and Hartig net formation was reported, proving that mycorrhization in the experiment was due to $S$. bovista treatment. Mantle and Hartig net thickness of plant roots treated with $S$. bovista and B. subtilis MB14 or S. bovista with $P$.

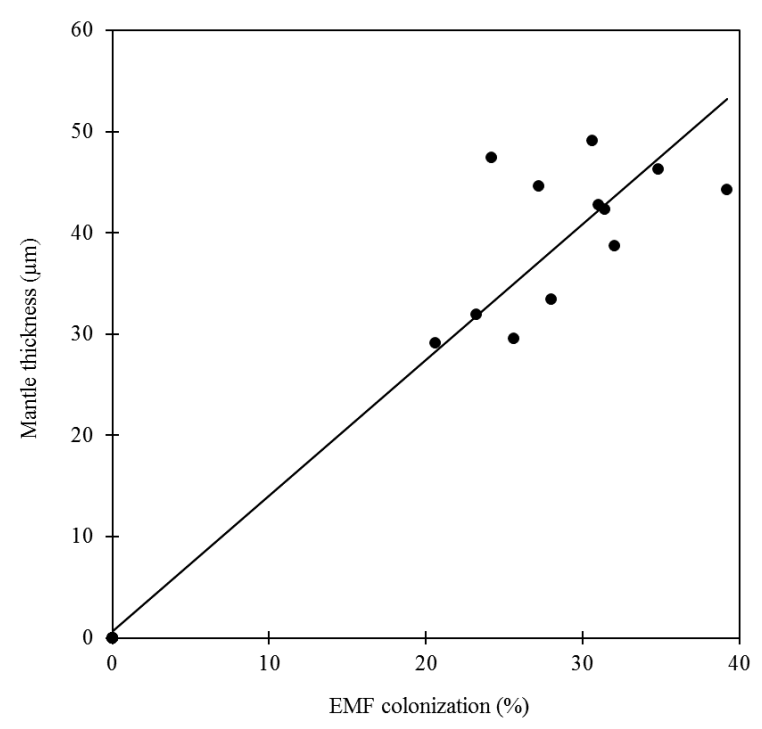

Fig. 5. Regression of fungal mantle thickness ( $\mu m)$ by EMF colonization (\%) $\left(R^{2}=0.946\right)$.

fluorescens MB9 was comparable to uninoculated control but lower than EMF control. This could be due to defensive effect of bacterial treatment, which might have restricted fungal growth in root tissues (Dahm et al., 1998). A strong positive regression of fungal mantle thickness $(\mu \mathrm{m})$ by EMF colonization (\%) was obtained (Fig. 5). Further study is needed to investigate possible mechanisms involved in the growth enhancement of the mycorrhizosphere bacteria towards the $S$. bovista growth.

\section{Conclusion}

Ectomycorrhizal symbiosis of $S$. bovista benefits banj oak growth and its symbiotic effects are further enhanced by co-treatment with B. subtilis MB14 and $P$. fluorescens MB9, respectively. Triple treatment of EMF with two bacteria provided even better results. Combination of EMF inoculant and mycorrhizosphere bacteria with different mode of actions strengthen the efficacy of growth promotion. Only bacterial treatment had no significant effect on plant growth, whereas treatment of $S$. bovista considerably stimulated plant growth. It is advantageous for $S$. bovista to be massively associated with host plant during planting out in order to be in a strong competitive position against other symbiotic fungi at the planting site. Co-inoculation with helper bacteria can help in faster colonization of EMF on plant roots.

It is clear from the results that bacterial strains $B$. subtilis MB14 and $P$. fluorescens MB9 could enhance mycorrhization in forest nursery practices where banj oak is grown for reforestation purposes. These two bacteria along with $S$. bovista, can therefore be exploited as forestry biofertilizer for $Q$. leucotrichophora plant. 


\section{REFERENCES}

Amijee, F., Tinker, P.B. and Stribley, D.P. (1989). The development of endomycorrhizal root systems. VII. A detailed study of effects of soil phosphorus on colonization. New Phytologist, 111(3): 435-446.

Aryal, H.P. and Budathoki, U. (2013). Ethnomycological studies on some macro-fungi in Rupandehi District, Nepal Banko Janakari, 23(1): 51-56.

Aspray, T.J., Frey-Klett, P., Jones, J.E., Whipps, J.M., Garbaye, J. and Bending, G.D. (2006). Mycorrhization helper bacteria: a case of specificity for altering ectomycorrhiza architecture but not ectomycorrhiza formation. Mycorrhiza, 16(8): 533-541.

Budi, S.W., Van Tuinen, D., Martinotti, G. and Gianinazzi, S. (1999). Isolation from the Sorghum bicolor mycorrhizosphere of a bacterium compatible with arbuscular mycorrhiza development and antagonistic towards soilborne fungal pathogens. Applied and Environmental Microbiology, 65(11): 5148-5150.

Dahm, H., Strzelczyk, E., Ciesielska, A. and Redlak, K. (1998). The effect of ectomycorrhizal fungi and bacteria on pine seedlings. Acta Mycologica, 33(1): 25-36.

Danell, E., Alström, S. and Ternström, A. (1993). Pseudomonas fluorescens in association with fruit bodies of the ectomycorrhizal mushroom Cantharellus cibarius. Mycological Research, 97(9): 1148-1152.

Dunstan, W.A., Malajczuk, N. and Dell, B. (1998). Effects of bacteria on mycorrhizal development and growth of container grown Eucalyptus diversicolor F. Muell. seedlings. Plant and Soil, 201(2): 241-249.

Duponnois, R. and Garbaye, J. (1991). Effect of dual inoculation of Douglas fir with the ectomycorrhizal fungus Laccaria laccata and mycorrhization helper bacteria (MHB) in two bare-root forest nurseries. Plant and Soil, 138(2): 169-176.

Duponnois, R. and Garbaye, J. (1992). Aplication of AMB (auxillary mycorrhization bacteria) during inoculation of douglas fir by Laccaria laccata S238 in a forest nursery. Revue Forestiere Francaise, 44(6): 491-500.

Duponnois, R. and Plenchette, C. (2003). A mycorrhiza helper bacterium enhances ectomycorrhizal and endomycorrhizal symbiosis of Australian Acacia species. Mycorrhiza, 13 (2): 85-91

Founoune, H., Duponnois, R., Ba, A., Sall, S., Branget, I., Lorquin, J., Neyra, M. and Chotte, J.-L. (2002a). Mycorrhiza helper bacteria stimulate ectomycorrhizal symbiosis of Acacia holosericea with Pisolithus alba. New Phytologist, 153(1): 81-89.

Founoune, H., Duponnois, R., Meyer, J.M., Thioulouse, J., Masse, D., Chotte, J.L. and Neyra, M. (2002b). Interactions between ectomycorrhizal symbiosis and fluorescent pseudomonads on Acacia holosericea: isolation of mycorrhiza helper bacteria (MHB) from a Soudano-Sahelian soil. FEMS Microbiol Ecol, 41(1): 37-46.

Frey-Klett, P., Pierrat, J.C. and Garbaye, J. (1997). Location and survival of mycorrhiza helper Pseudomonas fluorescens during establishment of ectomycorrhizal symbiosis between Laccaria bicolor and Douglas Fir. Applied and Environmental Microbiology, 63(1): 139-144.

Garbaye, J. (1994a). Tansley Review No. 76 Helper bacteria: a new dimension to the mycorrhizal symbiosis. New Phytologist, 128(2): 197-210.

Garbaye, J. (1994b). Transley Review No. 76: Helper bacteria: a new dimension to the mycorrhizal symbiosis. New
Phytology, 128: 197-210.

Garbaye, J., Churin, J.-L. and Duponnois, R. (1992). Effects of substrate sterilization, fungicide treatment, and mycorrhization helper bacteria on ectomycorrhizal formation of pedunculate oak (Quercus robur) inoculated with Laccaria laccata in two peat bare-root nurseries. Biology and Fertility of Soils, 13(1): 55-57.

Gong, M., Wang, J.-D., Zhang, J., Yang, H., Lu, X.-F., Pei, Y. and Cheng, J.-Q. (2006). Study of the antifungal ability of Bacillus subtilis strain PY-1 in vitro and identification of its antifungal substance (Iturin A). Acta Biochimica et Biophysica Sinica, 38(4): 233-240.

Hauer, R.J. and Dawson, J.O. (1996). Growth and iron sequestering of pin oak (Quercus palustris) seedlings inoculated with soil containing ectomycorrhizal fungi. Journal of Arboriculture, 22: 122-130.

Heinonsalo, J., Jorgensen, K.S., Haahtela, K. and Sen, R. (2000). Effects of Pinus sylvestris root growth and mycorrhizosphere development on bacterial carbon source utilization and hydrocarbon oxidation in forest and petroleum-contaminated soils. Can J Microbiol, 46 (5): 451-464.

Hetrick, B.A.D. (1989). Acquisition of phosphorus by VA mycorrhizal fungi and the growth responses of their host plants, Boddy, L., Marchand, R.M. and Read, D.J. (Eds.), Nitrogen, phosphorus and sulphur utilization by fungi. Cambridge University Press, Cambridge, pp. 205 -226 .

Karabaghli, C., Frey-Klett, P., Sotta, B., Bonnet, M. and Le Tacon, F. (1998). In vitro effects of Laccaria bicolor S238 N and Pseudomonas fluorescens strain BBc6 on rooting of de-rooted shoot hypocotyls of Norway spruce. Tree Physiology, 18(2): 103-111.

Kropp, B.R. and Langlois, C.-G. (1990). Ectomycorrhizae in reforestation. Canadian Journal of Forest Research, 20 (4): 438-451.

Kumar, A. and Ram, J. (2005). Anthropogenic disturbances and plant biodiversity in forests of Uttaranchal, Central Himalaya. Biodiversity and Conservation, 14: 309-331.

Kumar, M. and Sharma, C.M. (2009). Fuelwood consumption pattern at different altitudes in rural areas of Garhwal Himalaya. Biomass and Bioenergy, 33(10): 1413-1418.

Leyval, C. and Berthelin, J. (1991). Weathering of a mica by roots and rhizospheric microorganisms of pine. Soil Science Society of America Journal, 55(4): 1009-1016.

Ligon, J.M., Hill, D.S., Hammer, P.E., Torkewitz, N.R., Hofmann, D., Kempf, H.-J. and Pée, K.-H.v. (2000). Natural products with antifungal activity from Pseudomonas biocontrol bacteria. Pest Management Science, 56(8): 688-695.

Mahaffee, W.F. and Kloepper, J.W. (1997). Bacterial communities of the rhizosphere and endorhiza associated with field-grown cucumber plants inoculated with a plant growth-promoting rhizobacterium or its genetically modified derivative. Can J Microbiol, 43(4): 344-353.

Marx, D. (1970). The influence of ectotrophic mycorrhizal fungi on the resistance of Pine roots to pathogenic infections. V. Resistance of mycorrhizae to infection by vegetative mycelium of Phytophthora cinnamomi. Phytopathology, 60(10): 1472-1473.

Pinchuk, I.V., Bressollier, P., Sorokulova, I.B., Verneuil, B. and Urdaci, M.C. (2002). Amicoumacin antibiotic production and genetic diversity of Bacillus subtilis strains isolated from different habitats. Res Microbiol, 153(5): 269-276. 
Rizvi, R. and Khan, A. (2009). Response of Eggplant (Solanum melongena L.) to fly ash and brick kiln dust amended soil. Biology and Medicine, 1(2): 20-24.

Sarwar, S., Jabeen, S. and Khalid, A.N. (2013). Additions to ectomycorrhizae associated with Populus ciliata Wall. Ex Royle from Pakistan. Journal of Yeast and Fungal Research, 4(8): 98-102.

Schelkle, M. and Peterson, R. (1997). Suppression of common root pathogens by helper bacteria and ectomycorrhizal fungi in vitro. Mycorrhiza, 6(6): 481-485.

Schrey, S.D., Schellhammer, M., Ecke, M., Hampp, R. and Tarkka, M.T. (2005). Mycorrhiza helper bacterium Streptomyces AcH 505 induces differential gene expression in the ectomycorrhizal fungus Amanita muscaria. New Phytologist, 168(1): 205-216.

Sim, M.Y. and Eom, A.H. (2006). Effects of ectomycorrhizal fungi on growth of seedlings of Pinus densiflora. Mycobiology, 34(4): 191-195.

Singh, G. and Rawat, G.S. (2012). Depletion of oak (Quercus spp.) forests in the western Himalaya: grazing, fuelwood and fodder collection., Okia, C.A. (Ed.), Global perspectives on sustainable forest management. InTech.

Souto, E.B., Wissing, S.A., Barbosa, C.M. and Müller, R.H. (2004). Development of a controlled release formulation based on SLN and NLC for topical clotrimazole delivery. International Journal of Pharmaceutics, 278(1): 7177.

Uroz, S., Calvaruso, C., Turpault, M., Pierrat, J., Mustin, C. and Frey-Klett, P. (2007). Effect of the mycorrhizosphere on the genotypic and metabolic diversity of the bacterial communities involved in mineral weathering in a forest soil. Applied and Environmental Microbiology, 73(9): 3019-3027.

Weller, D.M. (1988). Biological control of soilborne plant pathogens in the rhizosphere with bacteria. Annual Review of Phytopathology, 26(1): 379-407.

Yadav, A., Bhatt, M. and Dubey, R.C. (2001). Characterization of mycorrhizosphere bacteria isolated from deodar and oak seedlings from Kumaun Himalaya. Journal of Indian Botanical Society, 80: 209-211.

Yadav, A. and Yadav, K. (2012). Physiological study of two ectomycorrhizal fungi isolated from Kumaun Himalaya. Indian Forester, 138(1): 17-21.

Yang, C.-H. and Crowley, D.E. (2000). Rhizosphere microbial community structure in relation to root location and plant iron nutritional status. Applied and Environmental Microbiology, 66(1): 345-351. 